\title{
A Review on Graffiti Phenomenon: A Study around Jakarta Indonesia
}

\author{
Bambang Winarso \\ Universitas Prof. Dr. Moestopo (Beragama) \\ Jl. Hang Lekir I No. 8, Senayan, Jakarta 10270, Indonesia \\ bbwinarso@yahoo.co.id
}

\begin{abstract}
Graffiti is often regarded as a form of social disruption and symbol of disorder in a region. This phenomenon is growing in many urban areas around the world. This paper aims to provide a social overview of graffiti phenomenon occurring in developing countries such as Indonesia, especially in urban areas of Jakarta. Through a qualitative approach, a review is obtained that the graffiti phenomenon in Jakarta is more likely a manifestation of existence of the graffiti actors both by individuals and groups in the social environment where they thrive. On the other hand, the social environment includes the people who tend to neglect and are lack of responsiveness in capturing the symbolic interaction emerged from the graffiti phenomenon.
\end{abstract}

Keywords: Graffiti; Social environment; Symbolic interaction; Urban phenomenon; Vandalism

\section{Introduction}

Historically, graffiti has been used by experts to reconstruct the history of Pompeii and Ancient Greek society [1]. According to Alonso in [1], graffiti is defined as small scratches derived from Italian graffiare which means scratches. For thousands of years ancient cultures have known this kind of literature expression. Therefore, according to Alonso in [1] graffiti can help unlock a unique insight into the society. However, nowadays, graffiti is more precisely defined as an act of vandalism that damages the property of others. Sampson and Raudenbush in [2] describe graffiti as a form of physical disorder triggering the deterioration of the urban landscape. Austin and Sander in [3] reveal that visual cue like graffiti gives local people the impression that their environment is slipping out of their control. The statements of Sampson \& Raudenbush in [2] and Austin \& Sander in [3] provide an overview of public perception today that graffiti is a symbol of disorder. Indonesia encounters the same thing. According to Barliana, et al. in [4], people living in big cities in Indonesia are currently experiencing various symptoms of social disorder that have become chronic problems, including vandalism. Graffiti has been a symbol of social problem in Indonesia because those streaks are seen as polluting the beauty of the city, as if the people no longer care about the cleanliness and beauty of the surroundings [5-8]. There is such thing as "vandalism" because many city corners in Indonesia filled with graffiti either containing a particular meaning or something meaningless [9-12]. Based on our observation, the scratching habit in cities and towns in Indonesia that adorns or defiles the walls in towns and villages has begun to increase since two decades ago. It could be a result of social and political reform, imitation of graffiti on the Berlin Wall, West Germany, or being inspired by the story of the freedom fighters who created the encouragement phrase like "Freedom or Death" on walls around the cities at that time.

The purpose of this paper is to provide the social point of view about the graffiti phenomenon occurring in developing countries such as Indonesia, especially in urban 
areas of Jakarta. The urban regions of Jakarta that includes the JABODETABEK (Jakarta, Bogor, Depok, Tangerang, Bekasi) area, as one of the biggest mega-polis region in the world, has a population of $29,466,772$ inhabitants in 2012 with a population density of 4,880 people per square kilometer. The population of Jakarta has reached 9.990 million inhabitants with a density of 14.700 people per square kilometer. With such large population density and its position as the center of economic growth in Indonesia, definitely Jakarta deals with a number of social issues including vandalism. Through this study, at least, social researchers are able to obtain a new portrait of the recent situation nowadays in many urban growth centers in developing countries.

The rest of this paper is organized as follow. Section 2 describes methodology. Section 3 describes concept of graffiti. Section 4 presents results and following by discussion. Finally, the conclusion of this work is presented in Section 5.

\section{Methodology}

This study applied a qualitative approach. According to Taylor et al. in [13], qualitative research uses a procedure to produce descriptive data in the form of written words or spoken words (orally). Meanwhile, Kirk and Miller in [14] defines that qualitative research is a certain tradition in social science that fundamentally depends on observation of humans in their own region and the connection with these people in their language and terminologies. This approach is utilized to interpret the phenomena occurring to or experienced by the research subject descriptively and conducted by involving various data collection methods.

This descriptive research is intended to get a systematic, factual, and accurate entry about the facts and properties of certain populations. Descriptive research method is a method to observe the status of a group of human beings, an object is a set of conditions, a system of thought, or a class of events in the present. The purpose of this descriptive research is to create a systematic, factual, and accurate description, a depiction or a view about the facts, properties, and the relation among the phenomena investigated [15]. This descriptive research method is conducted interpretively using a technique of in-depth interview with informants, observation on the research object, and the literature study related to the supporting theories, previous research, and so forth. Afterwards, data collection, data analysis and conclusion are carried out. Related to this description, the data collection using an observation technique is quite dominant, as symbols conveyed by the "bomber" through his scratches can be seen by the public, including researchers. Not only taking the field observation, I also held in-depth interview with several interviewees who are directly involved in the "bomber" action and with the informants attributed to the vandalism act. Some samples of adolescent groups that I interviewed who have performed the "bombing" activity are members of NBH (Not Bad Habit), i.e. Dn, By and Clnk; some are from the category among parents, teachers, community leaders, local officials, and security forces.

The research objects and locations are the writings, scratches on the walls of public facilities, bridges (flyover or underpass), shops, public places, information boards, walls of private property in housings, traffic signs, billboards, signposts, and etc. The main locations are along the streets I crossed in the morning, midday, or afternoon, starting from Pamulang, via Jl. Ciputat Raya, Ciputat flyover or underpass, Friday Market, Lebak Bulus, Kebayoran Lama, Jl. Arteri Pondok Indah, and other places around Jakarta and the surrounding areas. Some more locations are in housing areas in Bojongsari Sub-district, Depok, and South Tangerang areas such as: Renijaya Utama (old), Renijaya Utama (new), Pamulang Permai I, Pamulang Permai II, Witanaharja, Villa Pamulang, Pamulang Elok, Pamulang Village, Taman Sarua Permai, Villa Pamulang Mas, Bumi Mentari, and etc. 


\section{Concept of Graffiti}

According to Sampson and Raudenbush [2], graffiti is a form of physical disorder that impacts on the deterioration of the urban landscape. Austin and Sander in [3] reveal that the visual cue like graffiti gives local people the impression that their environment is slipping out of their control. On the other hand, the graffiti phenomenon is able to provide an overview of the social situation. According to Alonso in [1], graffiti provides a unique insight for the society because the message written through the graffiti is often made without social constraints that might limit the freedom of expression regarding the political ideas or controversial issues. According to Ferrel in [16], young graffiti writers tend to reject the structure of authority in which they are dwelling. By the nature of their activities, young graffiti writers violate the control shapes of urban space. When these violations further trigger the control, the graffiti writers usually counterattack, not only by direct confrontational manner, but also with the "adrenaline" that transforms legal pressure into a forbidden pleasure. According to Ferrell in [16], at the same time, the graffiti writers actually build alternative rules that form their identity and gain support from the community.

Alonso in [1] classifies graffiti into several types: political graffiti, existential graffiti, tagging graffiti, piecing graffiti, and gang graffiti. Political graffiti is the most open system, which means, that all parties who read this graffiti texts can understand the messages conveyed. The writers of geographical political graffiti put their writings in busy streets which ensure a broad view. Such graffiti employs the public as the audiences in communicating the ideas. Existential graffiti is the most common form of graffiti, and similar to the political graffiti. It contains personal comments of individuals; and sometimes it is called expressive graffiti. Existential graffiti can be divided into several subcategories that depend on the thematic content (sex, race, love, religion, philosophy, joke, and etc.). The geographical distribution of existential graffiti does not follow a pattern that can be identified in the urban environment, but can consistently be found in a public bathroom. Regardless if the content is associated with love, sex, or racial remarks, existential graffiti is the manifestation of personality. This inscription describes the ideas and sentiments that are usually taboo in the social life of us. Tagging graffiti is the graffiti expected to emerge in many different places as many as possible. Gaining recognition as a prolific graffiti writer is the goal. Fame and a sense of power are acquired by the numbers of the writer tags, indicating that he has completed graffiti in many places. The writer also perceives a sense of power by participating in such vibrant activities, and gives significant effects on his environment.

Piecing (or so-called bombing) is a decorative expression which requires artistic skill and understanding of aerosol paint application. Achieving fame as a "piecer" needs technical capabilities and more sophisticated style than just tagging graffiti. A piece of piecing graffiti work takes frequently one hour to complete using up to twenty aerosol cans. Piecing is a form of vandalism and artistic expression as well. Accepting graffiti as an art implies that piecing graffiti created in the right place is acceptable, and even beneficial. On the other hand, graffiti in the urban space is a crime, as if it challenges the authority hegemony of those who get power on the urban space. Gang graffiti serves as a way to communicate the sentiment and group identity and to dictate the rules in which they thrive socially. Messages, slogans and communicating symbols demonstrate the width of the area and the borderline of the gang. Based on the methods and tricks of making graffiti, generally the making process is similar. According to Weisel in [17] the graffiti actors often use spray paint and walls; in fact, they can also create graffiti with a big marker and/or on the surface of glass. Spray paint is widely available, easy to hide, easy and quick to use on various surfaces, available in various colors with different nozzles to change the line width - factors in providing the suitable spray paint for diverse actors. Weisel in [17] also added that the making of graffiti is characterized by anonymity 
in order to be relatively safe from detection, moreover, most actors work quickly and when there are few people around. According to Weisel in [17], graffiti making is mainly performed on late nights of weekends; in addition, the selected locations are often signified by the absence of person in charge in those regions. According to Gibbons in [18], if the graffiti is seen as a predictor of environmental degradation and the pioneer of the rising crime rate, it is no surprise that the graffiti brings an impact on the price of property. However, Gibbons' in [18] also indicates that such disorders as graffiti has a weak linkage if it is associated with more serious crime.

Alpaslan in [19] argues that although street art can be considered illegal almost everywhere in the world with only a few thorough exceptions, and street artists are seen as criminals; the fact that street art cannot be classified appropriately in one of the categories of crimes that have been set, raises the question of whether indeed it is the real crime. Such question is normally emerged because graffiti is difficult to measure precisely. According to Ley and Cybriwsky in [20], graffiti is an indicator of attitude, behavior and character of social process that is difficult to gauge directly. This gives the presumption that graffiti is standing in the gray zone. It also shows the individual factors of the actors become important to determine where the attitude and direction of graffiti will be taken. This indicates that the graffiti phenomenon cannot be overcome only with repressive ways but, instead, requires an individual approach that is more thorough and participative that directly involves the society. Sampson and Raudenbush in [2] suggest that the informal collective efforts of the citizens in resisting violation may provide unexpected benefits that will enhance the collective efficacy and reduce crime in the long term. Community approach is very significant for the public space order. According to Barliana, et al. in [4], social problem in the urban areas is the implication of the lack of social capital among the urban society. A broadly public-outreach approach in order to give more attention on their city and the interaction in public spaces becomes very important to build a better social condition in the urban areas.

A community approach can also be done by providing a forum and space so that the graffiti still get a place in society. This action has begun in many big cities all over the world. It helps the graffiti to take a part in the world of art. According to Radosevic in [21] graffiti subculture as the current dominant genre begins to be regarded as art. The term 'urban art' is getting prevalent as well. The graffiti phenomenon nowadays moves freely through discourse and genre to show the unity between them. Radosevic in [21] noticed the global phenomenon that there are a lot of graffiti actors starting to leave graffiti and get involved in the realm of street art and become an artist. Moreover, there are a lot of art performers like graphic designers who eventually enter the world of street art. It also has been occurring in Indonesia and certainly raises a new discussion about street art as a graffiti development towards a more positive direction.

\subsection{Graffiti in the Concept of Phenomenology and Symbolic Interaction}

Phenomenology is derived from Greek "phainomai" which means "perceptible" or visible. Phainomenon means the perceptible symptoms. In English, it is referred to: a) the science of phenomena as distinct from being (ontology); b) division of any science which describes and classifies its phenomena [22]. A phenomenon in general understanding is a particular symptom that is continuously or repetitively visible. The phenomenon can occur in the scope of events in the universe or the behavior of living organisms either humans or animals. Phenomenology is a course of philosophy as well as the theory and methodology. Phenomenology is likely a science that studies or tries to comprehend the phenomena coming up in the society which are mainly about life or social condition of the society and its characteristics. However, according to Endraswara in [23] the phenomenology itself rejects theories including the study of phenomenological philosophy of Schutz [24] and Husserl [25]. The study of life and social condition of a 
society depicts social reality of the knowledge that comes from the consciousness in everyday life. Husserl in [25] argues that the main principle as the foundation of philosophy is "consciousness". Therefore, what appears or being appeared continuously is regarded as a phenomenon. The action of doodles by the artists, which is made in the form of beautiful and meaningful mural on the walls in the city or just meaningless scratches by the "bombers", is a symptom or phenomena that can be observed as a new culture that may render a sense of adoration or dislike for some people.

A phenomenon is a reality that appears and can be seen, felt, touched, and so forth. Reality of the "graffiti" scratching as a work of the real artists and the "bombers" appears on the basis of consciousness of the doers. This consciousness is the awareness of something. Consciousness is naturally intentional, an essential element of the consciousness itself. Because consciousness is characterized by intentionality, then the phenomenon must be understood as something appearing. If associated with Husserl's opinion about the "phenomenological reduction" that states every material appearing in this world is not absolute, then the doodles we see on the walls of bridges, shops, housings, and etc., are also not absolute, because on the other side, there are certainly particular hidden meanings [25]. They convey messages through graffiti with an awareness of something. Socially, graffiti phenomenon can also be seen from the side of the symbolic interactionism. Symbolic interactionism theory leads to the understanding of the social interaction process and its consequences on the individual and society. According to Endraswara in [23] symbolic interactionism is a model of cultural research that seeks to uncover the reality of human behavior. The basic philosophy of symbolic interactionism is phenomenology. However, compared to the naturalistic and ethnographic research that also utilizes phenomenology, symbolic interactionism has its own paradigm. This model has begun to shift from the beginning. The original one was based on the cultural interaction interpersonally while the recent model has been related to the aspects of society or community.

Endraswara in [23] emphasizes that the symbolic interaction perspective attempts to understand culture through the human behavior reflected within the communication. Symbolic interaction underlines more on the cultural interaction signification of a community. Graffiti artists both professionals and the instant ones also perform their activities through the influences of their own community interaction. The behavior that appears in the form of phenomenon comes into a particular culture, exchanging meaning through their graffiti. Therefore, the essential meaning will be reflected through cultural communication between the communities and the locals. The messages conveyed through graffiti in public places or private property are the symbols of certain power basically created by a kind of consciousness; a supported motive. Bourdieu in [26] states that this condition is described as symbolic power, which is an invisible force that can only be perceived by those who object to such messages. According to Bourdieu in [26], symbolic system is art, religion and language, consisting of three instruments; structuring structures, structured structures, and instruments of domination. The tradition of NeoKantian (Humboldt-Cassirer or in the American variant is the Sapir-Whorf, as far as related to the language problem), examines the differences in the world of symbols such as myth, language, art and science as a tool or instrument to determine and construct objects as symbolic forms. Marx depicts it in his writing about Feuerbach as the active aspect of cognition. In the same tradition, but more focused on the problem of history, Panofsky views perspective as a historical form without requiring to reconstruct systematically the social conditions of the production process of these symbols.

According to Bourdieu, structuring structures is a tool to find and construct the objective world, while according to Kant-Cassirer, it is a symbolic form of the subjective structure. Durkheim, from Bourdieu's point of view, is obviously a part of the tradition of Kant. Consequently, it will give a positive and empirical answer to the problem of knowledge by avoiding the alternative priori based on the sociology of the symbolic 
forms. According to Cassirer, the concept of the symbolic form is similar with the form of classification. Meanwhile, according to Durkheim, classification is universal or transcendental that Panofsky called as social forms. In this idealistic tradition, subsequently, "the objectivity of the meaning or sense of the world is defined by the consent or agreement of the structuring subjectivities".

Furthermore, Bourdieu in [26] states that symbolic systems is structured structures. Symbolic system is as a structure that is structured. Symbolic system is a tool in communicating as language or culture versus discourse or behavior, while Hegel and Saussure declare it as symbolic object or objective structure. The objective meaning is as a product of communication which is the condition of the communication itself. Therefore, if the adherents of neo-Kantian emphasize on the "modus operandi" or productive activity of consciousness, then, the Structuralists emphasize on the "opus operatum" or the structured structures. Saussure, as the founder of the Structuralist tradition views that language (langue) is a structured system that is fundamentally treated as a structured medium calculating sound and meaning. The next study is the symbolic systems as instruments of domination. In the Marxist tradition, symbolic system emphasizes on the political function connected to logical structure and gynecological function that is related to law or regulation. The structural functionalism concept of Radcliffe-Brown [27] describes the production of symbols by associating them to the interests of the dominant groups. There are two syntheses presented by Bourdieu. First, as an instrument of knowledge and communication, symbolic structures can manage the power, simply because they themselves are structured. Second, in criticizing all forms of interactionist's errors which consists of reducing relations of power to the relations of communication system, it is not enough to just separately view the form and content. In fact, the forms of symbols and content also depend on the material symbols which are accumulated continuously. I found that both theories of phenomenology and symbolic interaction are suitable for evaluating the behavior of the "artists" who are members of "bomber" groups that increasingly break out. From the description above, consequently, the behavior of bomber is symbolic products to express the meaning expected to be understood by others.

\subsection{Graffiti Phenomenon in Various Cities in the World}

After the reform era, freedom of expression and creation is more optimally utilized by groups of adolescents who are supposed to have the right to express their opinions and identity. One way of expressing is by pouring words using paint or spray paint on walls, bridges (flyover or underpass), shops, public places, walls of private property in housings, traffic signs, billboards, and signposts. There must be a motive beneath their action. Moreover, it costs a lot of money. A lot of parties in Indonesia perceive that this phenomenon emerges and intensifies due to the lack of mental coaching to groups who behave negatively. In addition, the role of local government officials and security forces are often blamed because the supervision, anticipation, and prosecution of the actors are very weak, or it is assumed that there is no effort for those purposes. Meanwhile, the society itself is increasingly indifferent to their environmental conditions, especially the public environment.

Based on my experiences and observation of the graffiti work in some countries, there are some differences in attitudes and behavior of the society towards the beauty of their city depicting their strict rules on this issue. In West Berlin city before the "Bundes Einheit" or the unification of West Germany and East Germany marked by the collapse of Berlin Wall that stood firmly in 1989, the side of the Berlin wall facing to the West Berlin is full of graffiti containing expressions of opinions of West Berliners about the situation of their country at that time. There are a lot of blasphemed rants inscribed on the Berlin wall but created in the form of artistic and neat paintings or graffiti. While in the east side 
of the Berlin Wall, there is no graffiti existing because along the east wall there were mines, barbed wires, and armed guards especially the Russian army. In the city of Rome, Italy, it can be seen that there are two trains with inter-city rail service, which have significant difference. The first train is very clean; there is no graffiti on the walls. While on the wall of another train, it is covered with overlapping graffiti with colorful paint. Likewise, the wall of the railway station passed by trains is filled with all kinds of graffiti.

In the city of Melbourne, there are a lot of flyovers or highways bounded by varied artistic walls made by good materials such as granite, marble or ceramic, but they are still clean constantly. There is not even a line scratched on the both sides of the highway walls, they are still beautiful as they are. The Australian Government provides a space for graffiti artists or the bombers to express their talents in a graffiti competition which is usually followed by many participants. Meanwhile, in Singapore, not only by scribbling on the walls of public facilities and private property, but also by smoking or throwing the cigarette butts carelessly, people would be arrested and fined in accordance with applicable laws there. In the mean while, in Kuala Lumpur, the awareness of citizens towards the beauty of the environment and public facilities is also excellent. It has been proven how meek and obedient they are, including the young people who maintain the preservation of public facilities. What about the behavior of the residents in the United States? In most of the major cities in the United States, there are indeed a lot of graffiti scribbles on the walls. Street Crew posted about graffiti in the United States as follows:

"Graffiti was first discovered in America, since more and more bombers bombarding city corners in America, the government eventually began to provide an area for the bombers to express their works. In Philadelphia, for example, in 1984, the Philadelphia Anti-Graffiti Network (PAGN) which had been strongly opposed to this art eventually created a program called Mural Arts Program. This program provides a very decent place, but if the bombers are making graffiti outside the region, then they should be ready to accept the severe penalties. Graffiti now starts entering its golden age. Besides Indonesia, America, or precisely the Brooklyn Museum is often held exhibitions of graffiti which is now called contemporary art. Various professional bombers such as Crash, Lee, Daze, Keith Haring and JeanMichel Basquiat have become heroes in the art of graffiti" (http://graffitiindonesia.blogspot.com/ posted by: Screet Crew).

The phenomena in many urban areas indicate that graffiti starts to receive a space so that it can lead to a more positive direction. According to Radosevic in [21], this discourse has shifted the genre of graffiti to be a part of urban art or street art. This also gives a different insight that graffiti is also about the marginal individual actors whose status shift from the previous judgment considered to be a part of a crime or vandalism into professional artists who are actually appreciated by the society.

\section{Results and Analysis}

\subsection{Forms of Graffiti}

There are writings, scratches along the roads and on the walls, public facilities, bridges including flyover and underpass, shops, traffic signs, signposts, billboards; along the road I am passing-by every day, namely, Jl. Raya Pamulang II, Jl. Raya Ciputat, Jl. Raya Kebayoran Lama (Arteri), Jl. Raya Cireundeu - Pondok Cabe, Jl. Raya Parung, and etc. Some of them are writings that show school names as XMV (SMP), XMA (SMA), XTM (STM), or XMQ (SMK), also names of groups (gangs), and many other words in the form of unclear abbreviations, which certainly can only be understood by their own 
communities. If referring to Alonso in [1], this can be categorized as a gang graffiti which aims to demonstrate its territory. The selected group's name used often contains western influence. This condition indicates that the occurrence of this phenomenon more or less adapts some examples from the developed countries. Based on the conducted observation, there are words or graffiti that have existed for long, moreover, they are not erased or overwritten by other writings/graffiti until the color becomes dull. There are also piled writings/graffiti because they overwrite each other with different colors. There is a large graffiti expressing love to someone. There are also words that tend to be obscene or indecent. Those writings indicate an existential graffiti category. According to Alonso [1], existential graffiti is a manifestation of personality. This inscription describes the ideas and sentiments that are usually taboo in the social life of the creator. This shows that there is a graffiti that cannot be included in the piecing category that leads to an art. Graffiti existing in the city of Jakarta still aims to demonstrate the existence of individuals or groups (existential graffiti and gang graffiti) more than a graffiti that leads to street art.

Graffiti attempts to conquer the available space with the almost similar writing style. The group of these adolescents does not preserve the beauty/environmental hygiene, as when there is a flyover just recently completed, in a short time, it has been filled with graffiti. Even in Pondok Indah underpass and Ciputat Flyover, cleaning and repainting have been undertaken for times, but on the next day there are more strokes appeared. This certainly demolishes the city landscape, as the opinion of Sampson and Raudenbush in [2] says that graffiti is a form of physical disorder that impacts on the deterioration of the urban landscape.

The bombing action is performed in quiet times especially at night. In this case, I had conducted surveillance around my residence for several times at midnight. The groups consisting of adolescents coming from outside the residence passed quietly, and then when the action was completed, they half ran away from the object of graffiti. Referring to Weisel in [17], this is conducted for anonymity reason in order to be relatively safe from detection; moreover, most actors work quickly and when there are only few people around. According to Weisel in [17], graffiti making is mainly performed on late nights of weekends; in addition, the selected locations are often signified by the absence of person in charge in those regions.

Once my neighbor and I purposely intercepted a group of junior high school teenagers and asked what's inside their bags, but apparently there was one of them who ran away immediately. According to his friends, the kid brought a pilox (spray paint). Furthermore, there were also some kids playing in the afternoon and then randomly just pointed the markers or even pilox to a nearby wall. In this action, they used paint or pilox that they purchased by themselves, collecting dues, or given by someone. The spray paint is chosen because of its easy application, as what Weisel in [17] said that spray paints are widely available, easy to hide, easy and quick to use on various surfaces, available in various colors with different nozzles to change the line width — factors in providing the suitable spray paint for diverse actors.

\subsection{The Characteristics of Graffiti Actors}

There are several groups of graffiti painters in Indonesia, including Phantom Crew, Kilters Crew, Boraks Crew, Street Taint Crew and Screet Crew. However, except those organized groups, there are many more wild or seasonal "gangs" consisting of teenagers who just go along with it, or just demonstrate the existence of a particular group. Based on my observation, most of the graffiti actors who scratch on the walls, public facilities, bridges, shops, and private property are adolescents gathering in several small groups. The graffiti activity is done by young children/teenagers from elementary school, junior high or senior high school gathered in some small groups, consisting of 2-5 people; children from elementary and secondary school usually perform the graffiti around their 
residence. Meanwhile, the high school graffiti actors who usually use motorcycle are probably with an infinite distance of "bombing" targets, including the walls of roads, flyovers/underpasses, and etc. How do the street artists known as "bombers" perform their action? From whom do they obtain money to buy spray paint or pilox? Based on my conversation with a friend of my niece, he revealed that besides colleting "group dues", they also get the money from their living cost, sometimes there is a stranger who accidentally gives money to buy a pilox. The following statement of the "bombers" about their action is given in their site:

"A troop wearing sweaters and masks carrying spray paints in their hands began to walk through the streets in major cities of Indonesia. For several times they could remain silent under the flyover, with a significant look staring at the empty and dull wall. A second later, their hands started to spray the wall with spray paints. No one knew what they created at that time, until the next morning the street users began to wonder at the works of the bombers. And this is what we know as 'graffiti'" [28].

From the description above, it can be seen that when the "bombers" are to carry out the action, they are prepared as if they were going to fight or compete in the arena. They paid attention at the walls as the bombing target. They seemed to be not aware whether their "works" would have an impact on the city landscape or not.

\subsection{Some Important Notes}

Referring to the observation and interviews, there are several important factors to note about the description of the graffiti actors in Jakarta. These factors include:

\section{a. The Evidence of the Existence of the Graffiti Actors and Their Groups in the Social Environment}

The street walls are almost fully filled with scribbles. The places I am passing by every day are Ciputat flyover, Pasar Jumat underpass, Pondok Indah underpass, Kebayoran Lama Underpass, and so on. Likewise, when I observed the surroundings while driving around the Jakarta city or outside the city such as South Tangerang, Bogor, Depok and Bekasi, I found there is similar situation of the bombers' works distributed in all regions. The message delivery through graffiti increasingly has unclear meaning. Why do these things happen? Based on the statement of the actor from literature sources, their graffiti works are likely political graffiti and piecing graffiti that lead to demands for social space and art space. This condition can be seen from the following statement of Secret Crew:

"The existence of a significant social gap raises difficulties for certain groups of society to express their artistic works. As a result, some individuals use available spaces in almost all over the cities; walls. The education of arts is likely less to cause objects like writings and codes that often appear in the forms of graffiti as understood by certain groups. Generally, this work shows dissatisfaction of the social situation they are experiencing." [28].

However, based on my observation, the great number of graffiti in Jakarta does not indicate dissatisfaction dealing with the social problems, but more as a venue for self/group expression (graffiti existential). There is graffiti of school names and graffiti for declaration of love to a girl. Some words are likely obscene or indecent. Competition between groups can be seen in the overlapping graffiti. Thus, the symbolic interaction between groups of street artists and between society and them can be observed.

Based on the observation, there are individuals and groups who attempt to show their existence. Most of the individual actors are teenagers who simply show their existence off. There are some depictions emerged from my observation that can be taken as sample of cases. On such situation, there was a kid who performed graffiti on the wall around his house by himself. This is a concrete example that I knew based on the statement of the 
resident who deliberately snooped the person who always doodled newly painted walls around the residence. One night, he hid in a dark place in his yard, and around 1 a.m. he saw someone walking towards his house then sprayed something that turned out to be later known as pilox. He arrested the actor immediately who was still a teenager. $\mathrm{He}$ ordered the kid to clean what he had already written on the wall. Afterwards, the neighbors came to help the owner of the house. Then finally the parents of the kid came, and it turned out that his father is the village official. When he was asked about his motivation, the boy replied that he just did it on a whim like what his friends did. For the group actors, there are cases that I observed directly. Actually, it happened in my neighborhood. A group of teenagers scratched a kiosk rolling door on Sunday night. Incidentally, the village official was walking around the neighborhood to patrol. When the teens were in action, he immediately arrested some of them, and threatened to take them to the police. Because their identities were already known by him, then assisted by some locals who were coming over, they were freed under one condition that on the next day in the afternoon they had to clean or repaint the door of kiosk. What they have done was intended to show their existence. I conducted interviews with members of a group of graffiti actors a.k.a. Dn, By, and Clnk. Based on a similar confession, those teenagers were proud if their writings or their names are read by people, they felt like that they "existed" in their community or so-called a kind of existential graffiti. The existence of this group is growing toward a kind of competition between groups or leading to gang graffiti. They confessed that there is such competition between groups that are visible on the graffiti which is overwritten or crossed out. This competition is invisible in their environment and they tend to be introverted. Commonly, family or parents do not know what they are doing outside the house. Some members of this group quit the graffiti activities and made a community called NBH (Not Bad Habit) which is built based on the awareness that scratching walls is not a good activity and may harm others. They turned their attention to music (forming a musical band). The graffiti performers also take this condition as a challenge. This can be seen in the description of the graffiti actor groups as follows:

"At that time, on Saturday night, it was three of us escaping from our houses approximately at 11 p.m. We brought 12 cans of pilox. We sprayed it on any blank walls that we had been passing through. There were almost 27 walls that we scratched at that time. Finally at 2 a.m. when we were about to bomb a wall of someone's house, we saw someone walking. Then we just relaxed but suddenly he came back and took all of the pilox we had. We did not know who he was. He said, "Don't you even dare to run! You guys, I'll take you to the police station!" At the police station, we were interrogated aggressively. Oh Gosh! It was so thrilling! Then finally around 3 a.m. we were freed because we made a lot of excuses. Although the work was not completed, we've got a very exciting and thrilling experience!" [28].

The description above indicates that the action of the graffiti actors either individual or in groups, is not in the context of breaking the rules but rather for a reason of social resistance, challenges, and a kind of prank that entirely show the existence of the actors in their neighborhood. This must be an important note that in the development of big cities like Jakarta, it is essential to give more space for adolescents to distribute their concept of existence. This is a very important factor for the middle class society who is growing nowadays.

\subsection{The Factor of Neglecting Environment}

Children who are caught red-handed while performing their action are usually not responsible for what they have done even though they have been threatened to be reported 
to their parents, police or being told to clean up their graffiti. In this case, their environment has a role that is supposed to be very important. Based on the observation, I identify several authorized parties in the environmental level that regularly interact with graffiti actors, they include parents, community neighborhood, maintenance personnel, security forces, schools, local government and police. Based on the interview with parents, generally, they do not completely know what has been done by their children outside the house and school because almost every day they go to work in the morning and return home in the evening. Therefore, a lot of parents do not know, even trust, their children's behavior. The parents stated that their children scarcely perform bad things and would be embarrassed if they really do it. Regarding with the observation and interviews, the security forces and communities are not that concerned with the problem of wall scratching behavior because they tend to think that it is not part of their job. Occasionally, they reprimanded a group of teenagers who were still wandering in the middle of the night, but they did not take further action considering that most of the graffiti actors are adolescents. The society component has been involved enough, but they still have limitations. Some particular district officials have been trying to empower the citizens/teenagers in their neighborhood but the graffiti actors come from somewhere else outside their district. In my neighborhood, the teenagers are supported to participate in the religious activities in order to be unaffected by negative behaviors such as being a bomber, taking drugs, and etc.

The maintenance staff also becomes the disadvantaged party. The staff who does the painting said that he's only a worker receiving order to repaint the vandalized walls, particularly in Pondok Indah underpass. However, sometimes they feel annoyed because on the next day their work would be defiled again by graffiti. The other party that is also often asked for taking more important role is school. Based on the recognition, school has tried to steer their students for applying good behavior not scribbling on someone's walls or public facilities, instead, they are directed to take interest at sports, music as well as praying and studying as the main tasks of a student. In an interview with some teachers, there are still children/students who commit graffiti activity whose academic record is not good enough and they also join a student group who are a bit "naughty". However, school also has its limitations in protecting students after school hours. Besides the parties who interact directly on the field, there is a request from the citizens that the government, including the police and local government, to be involved as well. I have undergone three similar incidents of the arrest of an adolescent group of graffiti actors, one of whom is a child of the village official. I have yet to find the data declaring that the arrest and punishment (sanction) against the graffiti actors have been carried out by the authorities (local government, police, and etc.). However, such actions are clearly detrimental for the public's sake if the target objects are the traffic signs or signposts (vandalism). Furthermore, in the previous year, I have conducted some observations of graffiti on the walls, bridges (flyovers and underpasses) on my way to work and come home in the morning and afternoon. It was as if there was an acquiescence of the local government on the "bombers", so that whenever the workers clean up graffiti and the patches of advertising and repaint it, then on the next day there would be a new graffiti on those walls. This kind of incident is repeatedly occurring, between the workers who clean up the graffiti or advertising stickers and the "work" of the bombers giving the impression of omission and budget waste. In the areas of Jakarta, at some intersections, large-size billboards have been installed containing "Governor's Calling" for not doing vandalism along with an explanation of the sanctions. However, this does not seem to be a weapon without the direct community involvement. It is as the opinion of Sampson and Raudenbush in [2] who suggests that the informal efforts of citizens collectively to resist interference may provide unexpected benefits that will enhance the collective efficacy and reduce crime in the long term. The disregarding environment puts an important note in the city of Jakarta. Environmental factor of becoming increasingly individualistic society is a 
normal thing in urban areas. This should be a concern that public awareness should be more cultivated. Moreover, the influence of information and communication technologies such as television broadcast, mobile phones, internet, and etc., greatly affect the changes of attitudes and behavior of children. They are now getting cool with their own world. Without the optimal role of the environment including parents, the unwanted behavior will always be reappearing.

\subsection{Between the Symbolic Interaction and the Role of Neighborhood}

Graffiti as a work of doodling is often interpreted as a negative work because it is made without a clear pattern, regardless of the place, it is done quietly and people have no power over their actions, moreover, there is a tendency of meaningless works. There are some legal graffiti and many of which are illegal. As a symbolic expression of its maker, then according to the theory of symbolic interaction, graffiti is a form of social reality that is happening in the community. The initially interpersonal, occurring symbolic interaction has now penetrated into intercommunity or society and brought influence on social issues, problem of cleanliness, and beauty of the environment, and etc. The impact of social interaction through the work of graffiti has become a new phenomenon, which is actually has been there since a long time ago. However, in its development, the sense of graffiti has changed. In the past, people were expressing themselves for the sake of freedom and national independence by writing "freedom or death" on the walls, but now, the bombers are expressing themselves through graffiti in order to exist without a goal or just simply follow their friends. What happened with the work of graffiti is now a world of symbol, which according to Bourdieu is associated with art, religion, and language. Myth, language, art, and science have become a tool or instrument to determine and construct objects as symbolic forms of social conditions of our society. The motives which are based on the awareness of the bombers expressed in the form of graffiti on walls and public facilities are symbols of existence that can only be understood by the maker himself or his community. In fact, when the action is done, then graffiti actors have already been associated with legal issues and norms. The problem is when there is no law enforcement towards violations; then it will continue infinitely with unpattern form. This phenomenon will continue as a form of symbolic expression of those who are looking for identity and trying to bring himself and his group out. The behavior that makes "graffiti" illegal also occurs in other developed countries. The influence of information and communication technology, as stated by the informant, ES, is one of the causes of how the incidents in other places are known or can be easily accessed by children of this country.

Basically as what the study of Bourdieu and Durkheim conveys, each generation is a product of its era. Therefore, at the young age children find identity or express their thought through scratches on the walls; the period of time for one generation or group will only occur during one up to three years. After that, they will be getting older and carry out expression by other means in accordance with their age. Then the problem is how the parents and the community can find out what activities that have been done by teenagers in the neighborhood and how they can guide and direct the youth into better social activities. In a symbolic interaction theory, it is stated that what has been done by someone is on the basis of consciousness. However, in fact, when someone vandalizes walls, his consciousness is just a kind of awareness of what he is creating, not another consciousness that realizes the impact of his action. Therefore, it is actually a kind of "simulacra", a consciousness without the true awareness. Based on the brief interviews mentioned above, it can be seen that it needs actual actions from the environment such as the authorities, parents, schools, village officials, or local government, to prevent or minimize the action of the bombers and give wider space for teenagers. As an example, a broader space is actually provided in the city of Bandung. As a professional artist, Iweng 
created colorful images under the bridges and Jl. Pasupati Bandung, whose works can be enjoyed by all street users, because this action is based on the concept of maturity and clarity. It is also "legal" and he gets permission from the authorities, although in implementing the ideas and dreams he has to take his own expense. Unfortunately, this action is destroyed by similar illegal actions. This artist, who graduated from Bandung Institute of Technology, is very sad when his work is destroyed or overwritten by the graffiti of bombers using spray paint.

Another action that can be performed is providing competition space. Some of the street artists were awarded and even paid for expressing his talents in certain places in the form of murals. There is a mural painting that obtained an award of Indonesian World Records Museum (MURI Award) as the longest mural graffiti in Indonesia located in the city of Yogyakarta. The graffiti painting that was organized by the Youth Organization of Cilacap District in cooperation with the Department of Tourism, Cilacap held at the People's Amusement Park (THR; Taman Hiburan Rakyat) of Teluk Penyu Cilacap, has broken the MURI record for the implementation of the graffiti painting followed by 470 people, as reported by Antara News:

"Cilacap District, Central Java, on Sunday, was breaking Indonesian World Records Museum (MURI Award) for its mural painting with the largest participants (470), beating the previous record of 450 participants in Jakarta. Chairman of the organizing committee, Karsidi in Cilacap, on Sunday, said this activity, besides purposely to break the Muri record, it is also to provide a venue for developing the creativity of young people in arts. The activity was packaged as a competition to find the first up to the fourth champions which were divided into three categories: junior high school, high school, and public, while the prize were trophy and cash to the amount of IDR 4.5 million for each category (Antara News; www.blogger.com). The graffiti contest with the theme "A Million Scrathes Meanings - My City My Tourism" was attended by participants from Cilacap, Banyumas, Purbalingga and Banjarnegara. According to the Cilacap Regent, Mr. H. Probo Yulastoro, this activity aimed to provide a creativity space among young people so they will appear as professional artists from this area whether in a national level or even international level."

Children as a product of their era are possible to be monitored and controlled when at home or at school. But what about when they are outside of these two places? Then, indeed, the ones who got power on them while outside the house or school are their environment, the community, social condition, and the psychology of the children itself.

\section{Conclusion}

Referring to the typology of graffiti submitted by Alonso in [1], graffiti phenomenon in Jakarta tends to be more in the form of existential graffiti and gang graffiti. This phenomenon is a manifestation of the juvenile group effort to show their existence in the society. This condition depicts the lack of existential space provided by the city of Jakarta for the teenager residents. Bear in mind that graffiti is a social phenomenon, but as stated by Gibbons in [18] and Alpaslan in [19] it is difficult to categorize such action as a crime so that the treatment certainly requires different approaches. Therefore, local governments and communities must be able to provide a place for teenagers to devote their existence positively. The role of the communities becomes essential, as stated by Sampson and Raudenbush in [2] and Barliana, et al. in [4] in which the right approach to the problem of social disorder, including graffiti and vandalism, is the active involvement of the community. The description above also overviews that the graffiti phenomenon in the city of Jakarta is a representation of how urban people today tend to neglect and be 
unresponsive in capturing the symbolic interaction that appears in them. The phenomenon of graffiti continues to arise and it is not adequately limited by the community. The influence of urban areas has reduced the value of social capital that should have existed in the society. Such situation is where the government and the environment should contribute for the rebirth of social capital among the society so that people can also contribute more actively in the getting messages emerged in their social environment.

\section{Acknowledgement}

This research is supported by University of Prof. Dr. Moestopo (Beragama), Jakarta, Indonesia.

\section{References}

[1] Alonso, A. (1998). Urban Graffiti on the City Landscape, paper presented on Western Geography Graduate Conference, San Diego State University, February 14, 1998.

[2] Sampson, R.J. and Raudenbush, S.W. 'Systematic social observation of public spaces: A new look at disorder in urban neighborhoods', in American Journal of Sociology 105, no. 3: 603-651. University of Chicago Press: Chicago, 1999.

[3] Austin, D.M., and Sanders, C. 'Graffiti and Perceptions of Safety: A Pilot Study Using Photographs and Survey Data', Journal of Criminal Justice and Popular Culture, 14 (4), 2007.

[4] Barliana, M.S., Cahyani, D., and Paramita, B. The Urban Quality, Public Space, and Social Capital: Departing from Comparison of Three Cities. International Journal of Humanities and Social Science, 4, 10(1) August 2014.

[5] Lee, Doreen. "“Anybody Can Do It": Aesthetic Empowerment, Urban Citizenship, and the Naturalization of Indonesian Graffiti and Street Art." City \& Society 25.3 (2013): 304-327.

[6] Rachman, A. (2016). Digital Graffiti: Ekspresi Kreatif Di Lingkungan Digital. Brikolase Journal, 4(2).

[7] Gushendra, R. P. (2015). The Role of Graffiti and Mural as Alternative Public Sphere for Society. PEOPLE: International Journal of Social Sciences, 1(1).

[8] Widagdo, M. B. (2016). 3. Dramatisme dalam strategi penuangan gagasan melalui street art komunitas visual grafis. Jurnal Ilmu Sosial, 15(1), 24-34.

[9] Sugiana, A., Lee, K. S., Lee, K. S., Hwang, K. H., \& Kwak, W. K. (2015). Study on Interlocking System in Indonesia. 한국철도학회 학술발표대회논문집, 243-248.

[10] Arumsari, P., Arumsari, P., Rarasati, A. D., \& Rarasati, A. D. (2017). Maintenance strategy for public-rented residential building: a case study in Jakarta, Indonesia. Built Environment Project and Asset Management, 7(1), 99-110.

[11] Harish, S. P., \& Toha, R. (2017). A New Typology of Electoral Violence: Insights from Indonesia. Terrorism and Political Violence, 1-25.

[12] Spahn, H., Hoppe, M., Kodijat, A., Rafliana, I., Usdianto, B., \& Vidiarina, H. D. (2014). Walking the Last Mile: Contributions to the Development of an End-to-End Tsunami Early Warning System in Indonesia. In Early Warning for Geological Disasters 179-206. Springer Berlin Heidelberg.

[13] Taylor, S.J., Bogdan, R. and DeVault, M. Introduction to qualitative research methods: A guidebook and resource. John Wiley \& Sons, 2015.

[14] Kirk, J., and Miller, M.L. Reliability and validity in qualitative research. Sage, 1986.

[15] Rakhmat, J., Metode Penelitian Komunikasi. Remaja, Rosdakarya: Bandung, 2004

[16] Ferrell, Jeff, 'Urban graffiti: Crime, control, and resistance', in Youth and Society, 27, 73-92. Sage Publications, Inc: USA, 1995

[17] Weisel, D.L, Graffiti, Problem-Oriented Guides for Police, Problem-Specific Guides Series Guide No. 9, Office of Community Oriented Policing Services, U.S. Department of Justice: USA, 2004.

[18] Gibbons, S., 'The Costs of Urban Property Crime. The Economic Journal, 114: F441-F463, WileyBlackwell for the Royal Economic Society: United Kingdom, 2004.

[19] Alpaslan, Z. Is Street Art a Crime? An Attempt at Examining Street Art Using Criminology. Advances in Applied Sociology, 2(1), 2012, 53-58.

[20] Ley, D. and Cybriwsky, R. Urban Graffiti as Territorial Markers. Annals of the Association of American Geographers, 64(4), 1974, 491-505.

[21] Radosevic, L., 'Graffiti, Street Art, Urban Art: Terminological Problems and Generic Properties'in L. Koos (Ed.), New Cultural Capitals: Urban Pop Cultures in Focus (p. 3-14), Oxford: Inter-Disciplinary Press, 2004

[22] Kuswarno, E. Fenomenologi: metode penelitian komunikasi: konsepsi, pedoman, dan contoh penelitiannya. Widya Padjadjaran, 2009.

[23] Endraswara, S. (2008). Metodologi penelitian sastra. Niaga Swadaya.

[24] Schutz, A. (1967). The phenomenology of the social world. Northwestern University Press. 
[25] Husserl, E. (1970). The crisis of European sciences and transcendental phenomenology: An introduction to phenomenological philosophy. Northwestern University Press.

[26] Bourdieu, Pierre, Language and Symbolic Power, edited by: John B. Thompson, Polity Press, 1991

[27] Radcliffe-Brown, A. R. (1935). On the concept of function in social science. American Anthropologist, 37(3), 394-402.

[28] http://graffitiindonesia.blogspot.com/posted by: Screet Crew. 
International Journal of $\mathrm{u}-$ and $\mathrm{e}-$ Service, Science and Technology

Vol.10, No.8 (2017) 